\title{
Maaninka CowLab 2012
}

\author{
Mikko Järvinen ${ }^{1)}$ ja Jaakko Mononen ${ }^{1), 2)}$ \\ ${ }^{1)}$ Maa- ja elintarviketalouden tutkimuskeskus, Kotieläintuotannon tutkimus, Halolantie 31 A, 71750 \\ Maaninka, etunimi.sukunimi@mtt.fi \\ ${ }^{2)}$ Itä-Suomen yliopisto, Biologian laitos, Kuopion kampus, PL 1627, 70211 Kuopio, etunimi.sukunimi@uef.fi
}

\section{Tiivistelmä}

Nykyaikaisen lypsykarjapihaton teknologiatason mitoitus on haaste. Tuotannon mittakaavan kasvaessa maitotilat tarvitsevat tehokkaampia tuotannon ja tuotantoriskien hallinnan välineitä. Nykyaikaisesta navettateknologiasta on oikein hyödynnettynä huomattavaa apua maidontuottajalle. Maa- ja elintarviketalouden tutkimuskeskus MTT:n Maaningan toimipisteen tutkimuspihatto pyrkii vastaamaan maitotilojen tulevaisuuden haasteisiin toimimalla uusien ja kehitteillä olevien navettateknologioiden suomalaisena "koelaboratoriona" (Maaninka CowLab), josta kertyvä tieto ja kokemukset saadaan hyvin nopeasti siirrettyä maidontuottajien ja neuvojien sekä luonnonvara-alan opettajien opiskelijoiden käyttöön.

MTT:n Maaningan vuonna 2009 valmistunutta 120 lehmän tutkimuspihattoa varustetaan tutkimuskäyttöön kattavalla sensori- ja mittalaitekokonaisuudella. NYT Nykyaikainen navettateknologia hankekokonaisuus (2010-2012) tutkii vaihtoehtoja tutkimuspihaton monipuolisuuden lisäämiseksi ja samalla erilaisten laitteistojen toiminnan testaamiseksi. Hanke keskittyy kartoittamaan jo valmiiksi markkinoilla olevia myös tutkimuskäyttöön soveltuvia laitteistoja, joita ei vielä välttämättä ole saatavana Suomesta. Hankittujen laitteistojen asennuksen jälkeen niiden toimintaa, luotettavuutta ja käytettävyyttä testataan ja määritetään ovatko ne valmistajan lupausten mukaisia.

Tutkimuspihattossa on jo tällä hetkellä karkearehun syöntiä mittaavat laitteet, automaattiset järjestelmät märehtimisen mittaamiseen ja kiimojen tunnistamiseen sekä lehmän pötsin pH:n mittaamiseksi, erilaisia aktiivisuusmittareita sekä poikimisen ajankohdan ilmoittava järjestelmä sekä uusi tuotannonhallintajärjestelmä. Nämä järjestelmät ovat testausvaiheessa. Tutkimuspihaton varustelua lisätään vielä vuoden 2011 aikana elektronisilla maitomittareilla (EMM) ja progesteronimittareilla. Lehmien ontumista määrittävän järjestelmän hankintaa harkitaan kahdesta vaihtoehdosta. Myös eläinten laidunnus- ja lepokäyttäytymistä mittaavan järjestelmän hankinta on harkinnassa. Ympäristöolosuhdesensorijärjestelmää suunnitellaan mittaamaan tutkimuspihaton olosuhteita mahdollisimman kattavasti tutkimuksen taustatiedoksi.

MTT:n Maaningan tutkimuspihatosta kehitetään kansainvälistä CowLab tutkimusalustaa, jossa voitaisiin suorittaa hyvin monipuolisia tutkimuksia vähemmällä työmäärällä. Tavoitteena on kerätä eri järjestelmistä, mittalaitteista ja sensoreista tietoa yhteen suureen hakutietokantaan. Tämä tietokanta pystyisi palvelemaan tutkijoita myös internetin yli maailmalle.

Asiasanat: pihatto, tutkimusympäristö, sensoriverkko, navettateknologia 


\section{Johdanto}

Kotieläintuotannon yksikkökokojen kasvaessa nopeasti pihaton teknologiatason mitoitus on suuri haaste. ProAgrian tuotosseurannan tulokset 2010 osoittavat, että keskikarjakoko on lähes kaksinkertaistunut viimeisen kymmenen vuoden aikana, kun karjojen määrä on samassa ajassa vähentynyt puoleen (Nokka 2011). Tuotannon mittakaavan kasvaessa maitotilat tarvitsevat yhä tehokkaampia tuotannon ja tuotantoriskien hallinnan välineitä. Erityisiä kehittämiskohteita ovat yrittäjän jaksamista tukevat suunnitteluja automaatiojärjestelmät, tuotantoriskien minimointi sekä eläinten terveyden ja hyvinvoinnin reaaliaikainen seuranta. Vaikka suomalainen maidontuotanto on teknologiamyönteistä, ovat markkinat Suomessa verrattain pienet. Siksi kaikki tarjolla oleva teknologia ei rantaudu tänne Pohjolaan saakka. Aktiivisimmat ja tiedonjanoisimmat tuottajat liikkuvat itse maailmalla olevan tekniikan luo ja tuovat mukanaan hyviä käytäntöjä. Eturintamassa kulkevat tilaavat uusimpia laitteita suoraan ulkomailta ennen kuin niitä edes markkinoidaan Suomeen.

Nykyaikaista navettateknologiaa on jo käytössä monilla suomalaisilla maitotiloilla, mutta aiheeseen liittyvälle tutkimukselle ja koulutukselle on selkeä tarve. Teknologiaa hyödyntävät nimenomaan suuret lypsykarjatilat, ja suurten tilojen osuus maidontuotannossa kasvaa erittäin nopeasti. Nopea teknologian ja tietotekniikan kehitys tulee avaamaan maatalouteen uusia mahdollisuuksia, mutta samalla kuitenkin virheellisten kalliiden teknologiavalintojen mahdollisuus kasvaa. Tuottajat ovat pääasiassa laitevalmistajien tarjoaman informaation varassa, ja kokemus on jo osoittanut, että laitteet eivät ole esimerkiksi luotettavuudeltaan aina vastanneet tuottajien odotuksia.

Maa- ja elintarviketalouden tutkimuskeskuksen MTT:n uusin 120 lehmäpaikkainen tutkimuspihatto valmistui Maaningan Halolaan huhtikuussa 2009. Maaninka sijaitsee Pohjois-Savossa, joka on Suomen toisiksi suurin maidontuottaja (Matilda Maataloustilastot 2011). Maaningan tutkimuspihattoa kehitetään vastaamaan sekä kotimaisen maidontuotannon teknologisiin haasteisiin että kansainvälisesti ajankohtaisiin tutkimuskysymyksiin. Tavoitteena on luoda sekä kansallisesti että kansainvälisesti houkutteleva tutkimusympäristö, joka tarjoaa monipuoliset mahdollisuudet tutkimukseen, kehittämiseen sekä teknologianja tiedonsiirtoon. Nykyaikainen navettateknologia -hankekokonaisuuden (NYT) myötävaikutuksella luodaan Maaningalle nykyteknologiaan perustuvaa korkean tason tutkimus- ja kehitysympäristöä eli tutkimusalustaa. Tutkimusalusta ja siihen liittyvä osaamisverkosto tukee alueen maitoelinkeinoa tuottamalla tarvelähtöisesti nykyaikaisten navettateknologioiden kehitys-, testaus- ja koulutustoimintaa tiiviissä yhteistyössä muiden itäsuomalaisten maidon alkutuotannon osaajien kanssa. MTT:n Maaningan tutkimuspihatto vastaa maitotilojen tulevaisuuden haasteisiin toimimalla uusien ja kehitteillä olevien navettateknologioiden suomalaisena "koelaboratoriona" (Maaninka CowLab), josta kertyvä tieto ja kokemukset saadaan hyvin nopeasti siirrettyä maidontuottajien, opettajien, neuvojien sekä luonnonvara-alan opiskelijoiden käyttöön.

NYT-hankekokonaisuus koostuu kahdesta toisiaan tukevasta hankkeesta. NYT Nykyaikainen navettateknologia instrumentointihankkeen rahoittaja on Pohjois-Savon liitto (EAKR) 495000 eurolla ja NYT Nykyaikainen navettateknologia osaamisverkostohanketta rahoittaa Pohjois-Savon elinkeino-, liikenneja ympäristökeskus (ESR) 545000 eurolla. Hankkeiden kesto on 1.1.2010 - 31.12.2012.

\section{Maaninka CowLab kehittyy ja monipuolistuu}

MTT:n Maaningan toimipaikan tutkimuspihatossa on 120 lehmäpaikkaa neljässä osastossa, kymmenen poikimiskarsinaa sekä 12 parsipaikkaa. Lypsy tapahtuu pihaton keskellä olevalla 2x8 kalanruotoasemalla (SAC 115B, Tanska). Tutkimuspihaton alkuperäiseen kokoonpanoon yleisen lypsyasemapihattovarustelun lisäksi kuuluu 12 paikkainen RIC ruokintajärjestelmä (Roughage Intake Control, Insentec, Hollanti) kahdessa 24 lehmän osastossa. RIC ruokintajärjestelmän mittaa syödyn karkearehun määrän yksilöittäin sadan gramman tarkkuudella ja yksilöiden pääsy eri ruokintakupeille on ohjelmoitavissa. Tutkimuspihatossa on mahdollisuus ruokkia automaattisesti neljältä täyttölaitteelta (Pellon Compact FD, Pellon Group, Suomi) neljää erilaista karkearehua (appeena tai erillisruokintana) kahdella pihattosukkulalla (Free stall robot, Pellon Group). Pihattosukkulat pystyvät liikennöimään koko pihaton alueella ja ne myös punnitsevat jakamansa rehun määrän. Kolmea vaihtoehtoista väkirehua jaettaan viideltä yksilöt tunnistavalta väkirehukioskilta (Pellon Group), joissa on myös elopainovaa'at. Alkuperäisellä kokoonpanollaan tutkimuspihatto mahdollisti ennen kaikkea ruokintatutkimuksen, mutta varsinkin eläinten käyttäytymisen ja hyvinvoinnin tutkimus joutui nojautumaan perinteisiin, hyvinkin työläisiin tutkimusmenetelmiin (esim. käyttäytymisen suora seuranta).

NYT -hankkeen myötä MTT:n Maaningan toimipaikan tutkimuspihattoon on jo asennettu mielenkiintoista uutta teknologiaa. Hankittavista laitteet ja järjestelmät ovat jo maailmalla kaupallisesti saatavia ja periaatteessa kenen tahansa hankittavissa. 
RuminAct (Milkline, Italia) terveydenseurantajärjestelmä mittaa automaattisesti eläinten aktiivisuutta tunnistaen kiimoja ja laskee eläinten märehtimiseen käyttämää aikaa (Kuva 1). RuminAct ei ollut vielä Suomessa kaupallisesti saatavilla kun se asennettiin kahteen MTT:n lypsykarjanavettaan, Maaningalle ja Minkiöön. RuminAct antaa hälytyksen kun eläimen, hiehon tai lehmän, aktiivisuudessa tai märehtimisessä tapahtuu muutos. Eläinten aktiivisuus ja märehtiminen antavat molemmat ennusmerkkejä hyvinvoinnista ja tuotannosta. Aktiivisuutta, kiimahälytyksiä ja tuotantoa voidaan seurata myös Nedap Lactivator (Nedap, Hollanti) järjestelmän kautta.

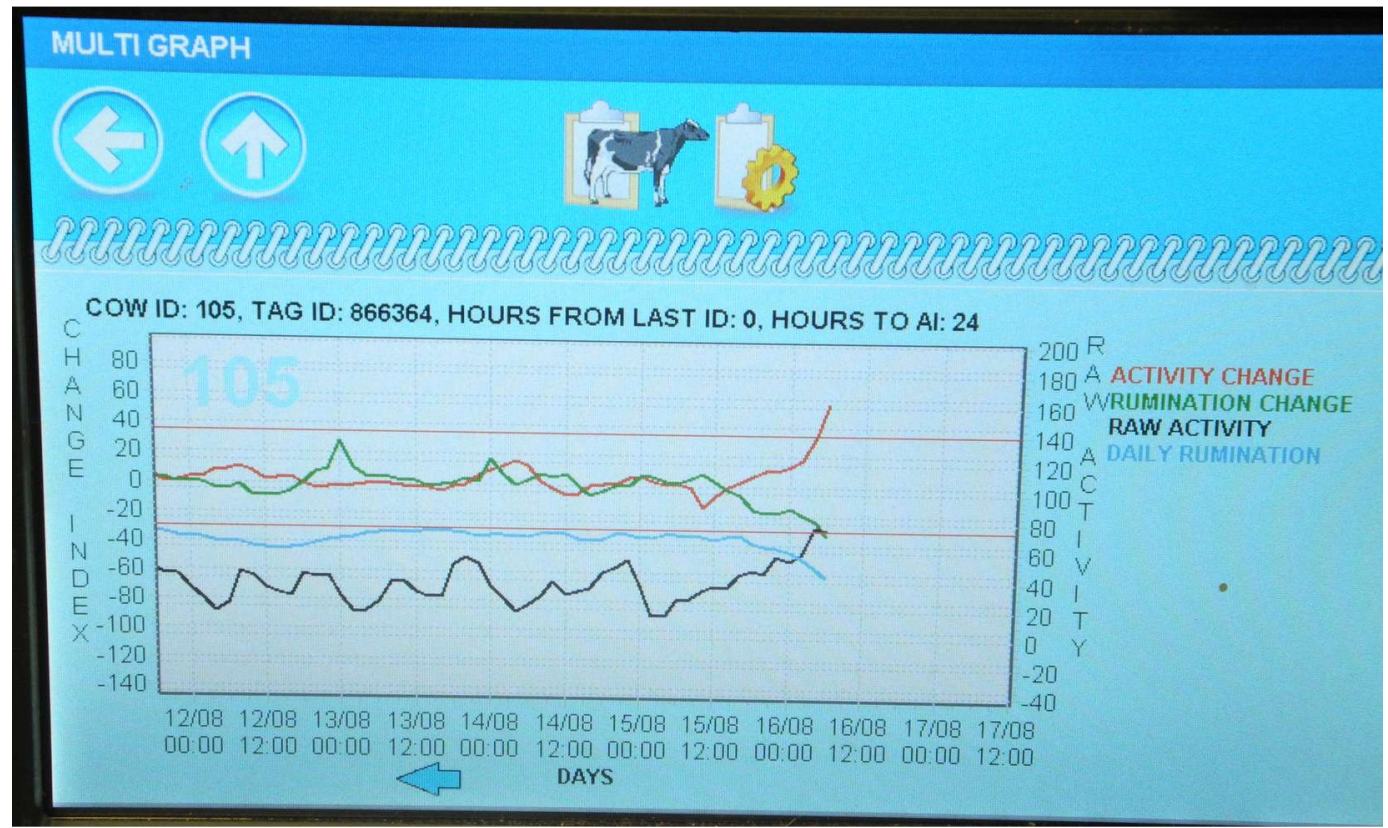

Kuva 1. RuminAct:n ruudulta on helppo seurata eläinten aktiivisuutta ja märehtimistä.

Esimerkkilehmän aktiivisuus on kasvanut ja märehtimiseen käytetty aika vähentynyt viimeisen kahden vuorokauden aikana. RuminAct ehdottaa lehmän siementämistä 24 tunnin kuluttua. Kuva: MTT

Eläinten pötsin pH:ta ja lämpötilaa mitataan smaXtecin (Itävalta) pH boluksilla (Kuva 2). Maaningalle toimitettiin kesällä 2011 smaXtecin ensimmäiset tehdasvalmisteiset bolukset. Bolusten avulla tutkimuseläinten ruokintaa on mahdollista säätää yksilötasolla tarkemmin kuin laskennallisesti. Jatkuvan langattoman seurannan avulla on mahdollista mallintaa myös eri ruokintavaihtoehtojen ja rehujen vaikutuksia pötsin happamuuteen ilman, että eläimestä tarvitsee ottaa pötsinäytteitä. Bolusten käyttöaika pH:n mittaamiseen on 50 vuorokautta, jonka jälkeen mittaustulokset eivät enää ole luotettavia.

Agrimonitor poikimisvyön (Databel Trading, Belgia) soveltuvuutta poikimisen valvontaan selvitettiin loppukesästä 2011 (Kuva 3). Agrimonitor mittaa lehmän utareiden etupuolelle sijoitetun vyön kireyden muutoksia ja lähettää algoritminsa mukaisesti tarvittaessa hälytyksen keskuslaitteen kautta kännykkään. Poikimisvyö on kehitetty alun perin Belgian Blue rotua varten, mutta sitä voidaan käyttää myös muilla roduilla. Alustavat tulokset poikimisvöistä olivat lupaavia, mutta lisää tutkimusta tarvitaan todellisen hyödyn selvittämiseksi. Myös muita poikimisen valvontaan tarkoitettuja apuvälineitä on tarkoitus testata. 


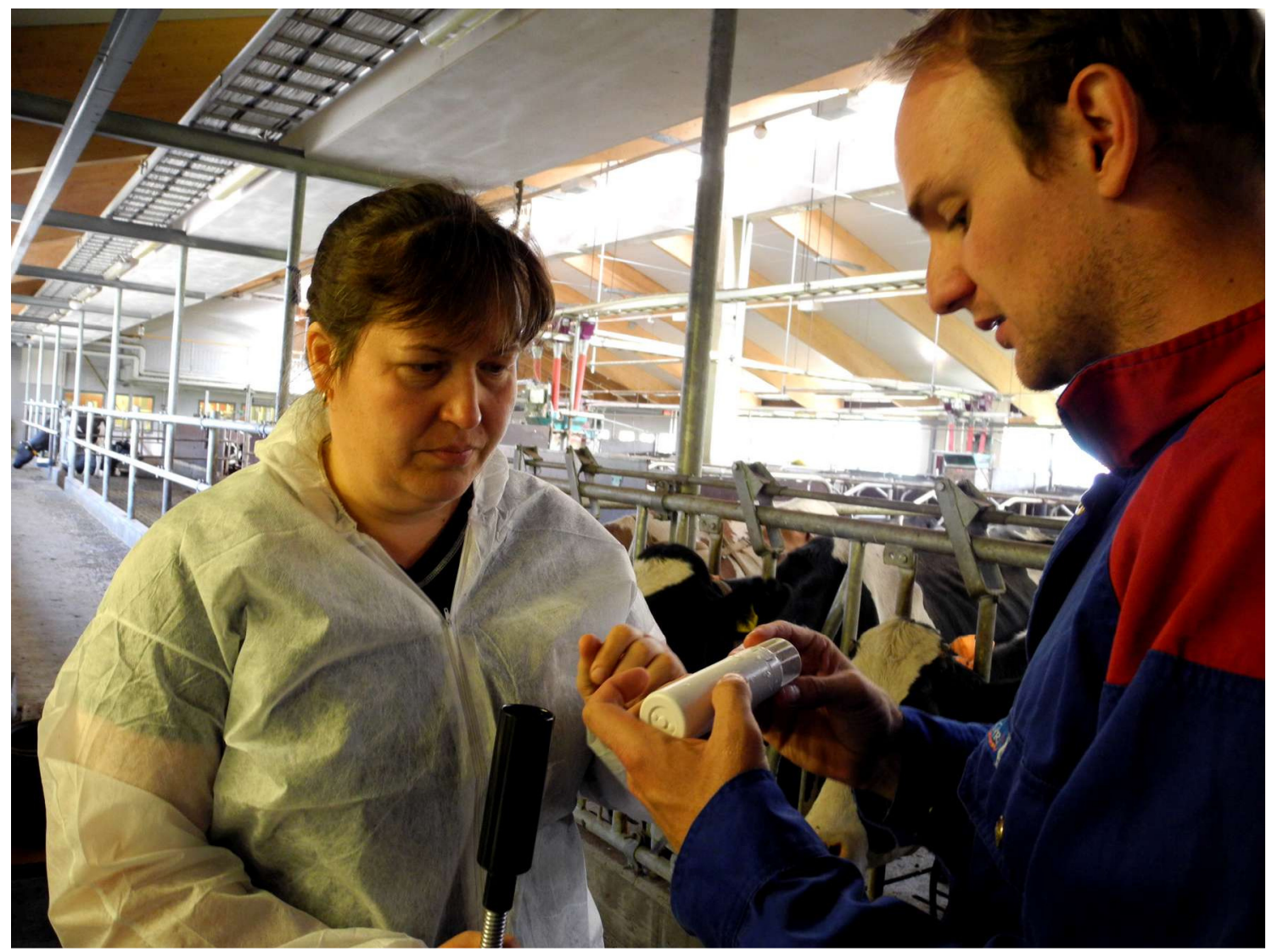

Kuva 2. Ell Kaisa Hartikainen ja smaXtec:n teknikko Gerhard Zancolo tarkastavat boluksen (132x35 $\mathrm{mm}$ ) ennen sen sijoittamista suun kautta lehmän pötsiin. Kuva: MTT

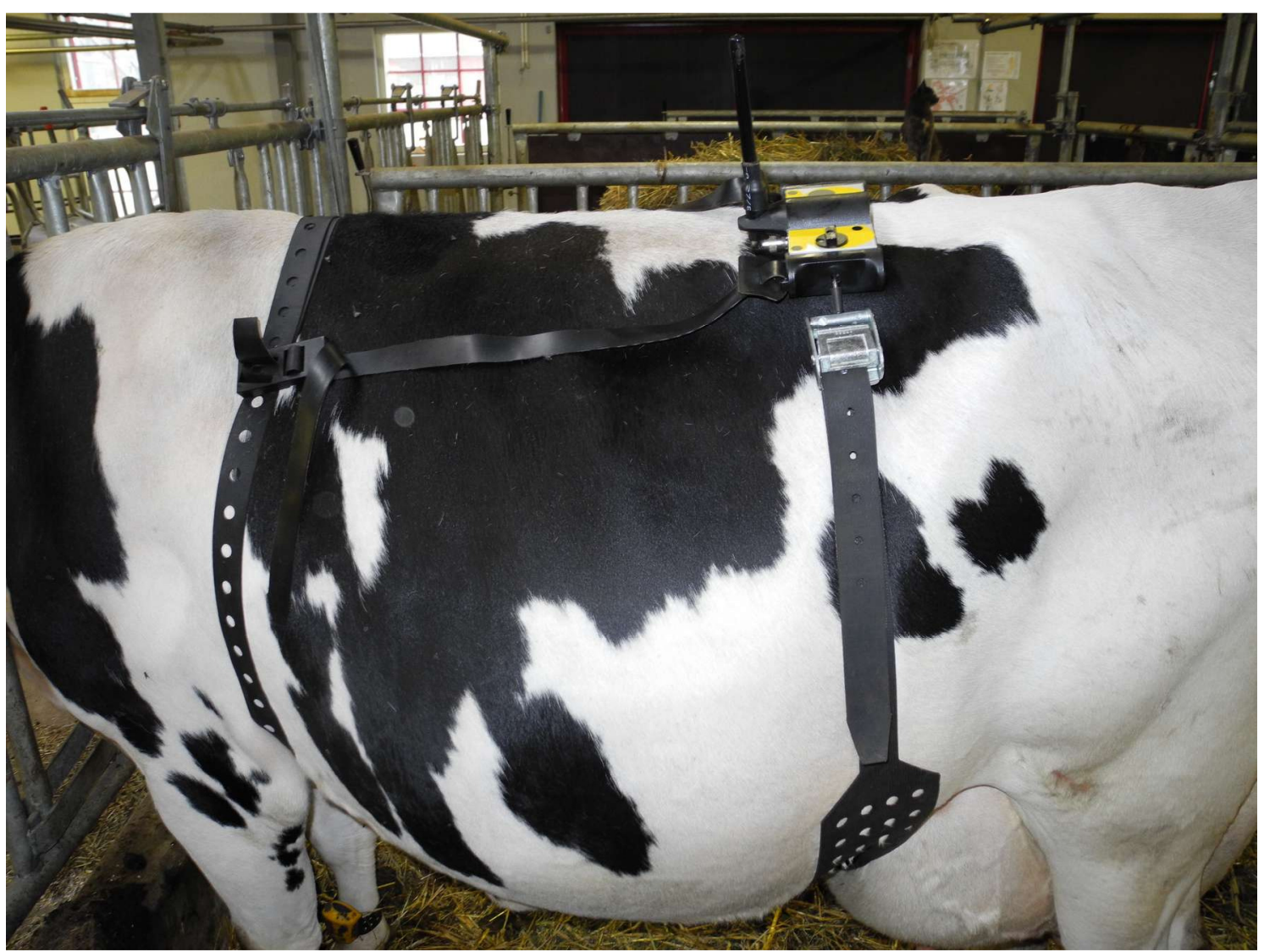

Kuva 3. Agrimonitor yksikkö (oikealla ylhäällä) mittaa utareiden etupuolelle sijoitetun vyön kireyden muutoksia. Kuva: MTT. 
Tuotannonohjaukseen käytetään Pellon Groupin toimittamaa Multiline tuotannonohjausjärjestelmää. Kaikki edellä mainitut laitteet poikimisvyötä lukuun ottamatta mittaavat tietoa häiritsemättä eläintä. Mitattu tieto siirtyy langattomasti kunkin laitteen omaan tietokantaan, josta se on tutkijan käytettävissä. Tutkimuspihaton yleisvalvontaan ja tutkimuskohtaiseen valvontaan on käytettävissä kattava videovalvontajärjestelmä (ASANTech Pro NVR, ASAN Security Technologies Oy, Suomi).

Eläimistä voidaan mitata yksityiskohtaisempia asento ja kiihtyvyystietoja Wirepas Oy:n (Suomi) toimittamalla 3-D kiihtyvyysmittausjärjestelmällä. Järjestelmän avulla pystytään mallintamaan eläinten eri käyttäytymismuotoja. Muun muassa käyttäytymismuotojen tunnistamisessa NYT-hanke hyödyntää aiemmissa Hyvin älykäs navetta (HÄN) ja Käyttäytymisen analysointi paikka- ja liiketiedon avulla (KAPLA) hankkeissa saatuja tuloksia (Martiskainen ym. 2009, Hämäläinen ym. 2011).

Tällä hetkellä toimituksessa ovat elektroniset maitomittarit (EMM) (Tru-Test, Uusi-Seelanti) sekä progesteronimittarit eProCheck 2.0 (Minitube, Saksa) ja HealthyLab PG20 (Milkline, Italia). Elektroniset maitomittarit mittaavat maitomäärän, lypsyajan ja maidon virtausnopeuden. Maitomittarit ottavat koko lypsyn kestolta maitoa näytesäiliöön, missä sitä sekoitetaan ja lopuksi edustava näyte siirtyy viivakoodilliseen näytepulloon. Maitomittareiden mittaustiedot siirtyvät käytettävästä käsikapulasta internetin yli Maatalouden laskentakeskuksen ja meijerin käyttöön. Tutkimuskäytössä Tru-Testin elektronisten maitomittarien odotetaan tuovan merkittävää tehokkuutta ja varmuutta maitonäytteiden ottamiseen ja hallintaan. Maidosta progesteronitasoa analysoivia siirrettäviä mittareita testataan niiden hyödyn, käytettävyyden ja kustannustehokkuuden kannalta. Omilla mittareilla tutkimuspihatossa saadaan välittömästi analyysitieto halutusta kohteesta ilman päivien viivettä, joka syntyy kun näyte lähetetään analysoitavaksi muualle.

Suunnitteluasteella on ympäristöolosuhdesensorijärjestelmä, joka mittaisi ja tallentaisi jatkuvasti mm. lämpötilaa, kosteutta, valonvoimakkuutta, melutasoa sekä kaasuja (mm. metaani, ammoniakki, asetoni). Antureita on tarkoitus asentaa pihaton eri puolille mahdollisimman edustavasti. Anturit keräisivät ja tallentaisivat tietoa ympäristön olosuhteista tutkimustoiminnan taustatiedoksi. Lehmien sorkkien kuntoa automaattisesti määrittävän StepMetrix (Boumatic, USA) hankintaa on valmisteltu jo jonkin aikaa. Hankintaa pidettiin itsestään selvyytenä kunnes kansainvälisen yhteistyön kautta tuli esille, että Hollannissa kehitetään vastaavaa, mutta kehittyneempää järjestelmää nimeltään Gaitwise.

Myös IceRoboticsin (Iso-Britannia) laiduntamista, aktiivisuutta (ml. askelmäärä) ja makuukäyttäytymistä mittaavan IceTag laitteiston hankintaa on valmisteltu. Tämän hankinnan valmistelun aikana saadut kokemukset kuvaavat hyvin ongelmia, joita hankinnoissa saatetaan kohdata: laitteistoa markkinoitiin jo syksyllä 2010, kunnes loppukesällä 2011 tuli ilmi, että laitteisto ei ollut laidunnusanturin osalta vielä tuolloinkaan valmis myyntiin.

Hankintojen ja meneillään olevien testausten taustalla seurataan jatkuvasti uusien laitteiden ilmestymistä markkinoille. Varsinkin Euroopassa ja Pohjois-Amerikassa pidettävät kansainväliset alan messutapahtumat ovat olleet hyviä tietolähteitä tuotteista, jotka ovat vasta tulossa Suomeen seuraavien lähivuosien aikana.

Kaikki tieto mitä MTT:n Maaningan toimipisteen tutkimuspihatosta kerätään automaattisesti on tarkoitus koota kehitettävään tietokantasovellukseen. Tietokannasta tutkija pystyy helposti hakemaan haluamansa tiedot haluamistaan eläinyksilöistä ja ryhmistä. Tavoitteena on, että tietokantaa voidaan käyttää internetin yli mistä päin Suomea tai maailmaa tahansa.

Maaninka CowLab tutkimusalusta ei ole vielä täysin toimintavalmis, mutta tarjoaa jo nyt varsin hyvät resurssit lypsykarjatutkimukselle ja herättää kiinnostusta kansainvälisestikin.

\footnotetext{
Kirjallisuus

Nokka S. 2011. Tuotosseurannan tulokset 2010. Tulosseminaari 14.4.2011. ProAgria Keskusten Liitto, Vantaa. Matilda Maataloustilastot. 2011: Maidontuotanto ELY-keskuksittain kiintiökausilla 2009/10 ja 2010/11 (27.5.2011). Maa- ja metsätalousministeriön tietopalvelukeskus. http://www.maataloustilastot.fi/alueittainen-maidontuotanto.

Martiskainen, P., Järvinen, M., Skön, J-P., Tiirikainen, J., Kolehmainen, M. \& Mononen, J. 2009. Cow behaviour pattern recognition using a three-dimensional accelerometer and support vector machines. Applied animal behaviour science 119: 32-38. doi:10.1016/j.applanim.2009.03.005

Hämäläinen, W., Martiskainen, P., Järvinen, M. \& Mononen, J. 2011. Jerk-based feature extraction for robust activity recognition from acceleration data. In: Proceedings of the 11th International Conference on Intelligent Systems Design and Applications (ISDA), s. 831-836, 22-24.11.2011,Córdoba, Espanja.
} 